\title{
DRILLING, CONSTRUCTION, AND CALIPER-LOG DATA FOR WELL 3-3204-01, KAHEAKA EXPLORATORY WELL, OAHU, HAWAII
}

U.S. GEOLOGICAL SURVEY

Open-File Report 96-421

Prepared in cooperation with the CITY AND COUNTY OF HONOLULU BOARD OF WATER SUPPLY
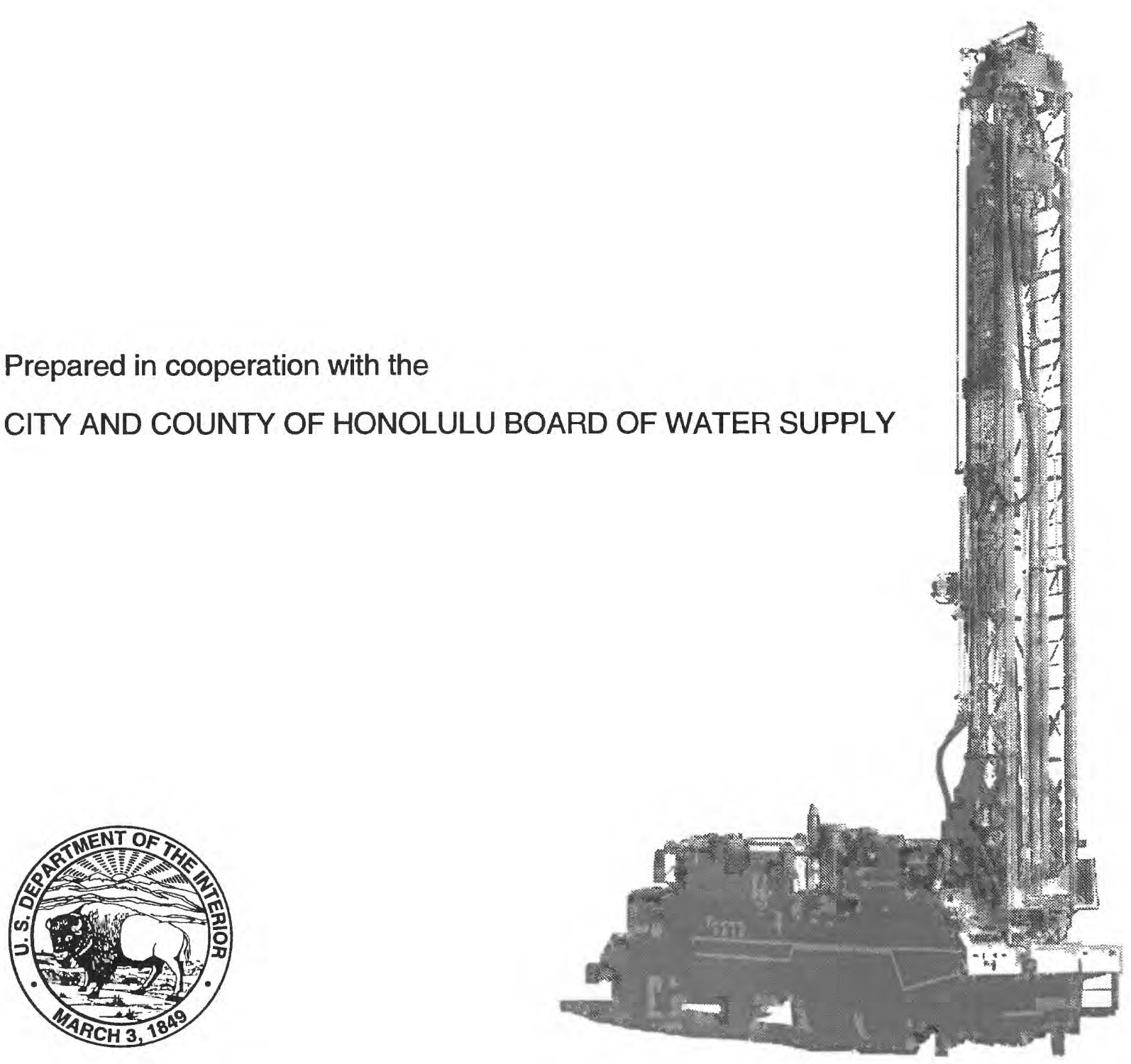


\section{U.S. DEPARTMENT OF THE INTERIOR BRUCE BABBITT, Secretary}

\section{U.S. GEOLOGICAL SURVEY}

Gordon P. Eaton, Director

Any use of trade, product, or firm names in this publication is for descriptive purposes only and does not imply endorsement by the U.S. Government

For sale by the

U.S. Geological Survey

Branch of Information Services

Box 25286

Denver, CO 80225-0286

For additional information write to:

District Chief

U.S. Geological Survey

677 Ala Moana Blvd., Suite 415

Honolulu, HI 96813 


\section{CONTENTS}

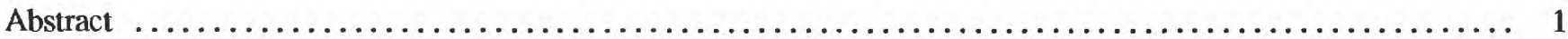

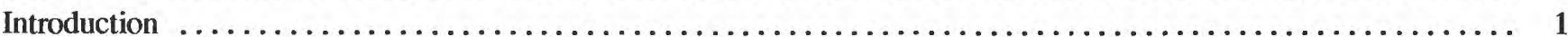

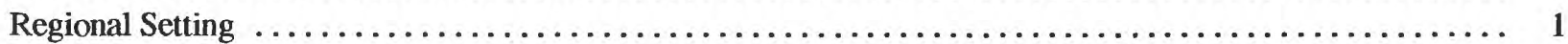

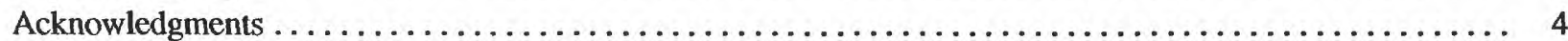

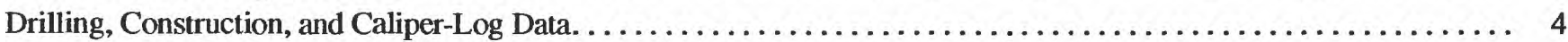

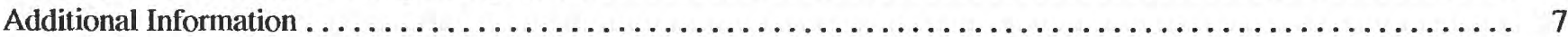

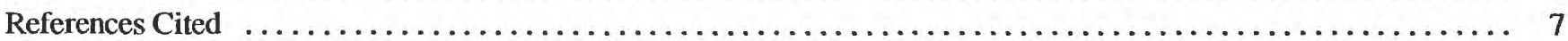

\section{FIGURES}

1-2. Maps showing:

1. Ground-water areas of north-central Oahu and wells drilled during the study, Hawaii . . . . . . . . . 2

2. Location of Kaheaka exploratory well, Oahu, Hawaii . . . . . . . . . . . . . . . . . . . 3

3. Diagram showing construction details for Kaheaka exploratory well (State well number 3-3204-01),

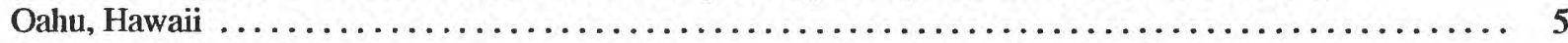

4. Graph showing caliper log for the Kaheaka exploratory well (State well number 3-3204-01), Oahu, Hawaii . . . . 6

\section{TABLES}

1. Construction data for Kaheaka exploratory well, Oahu, Hawaii. ........................ 4

2. Geologic $\log$ for Kaheaka exploratory well (State well number 3-3204-01), Oahu, Hawaii . . . . . . . . . . 7

3. Driller's $\log$ for Kaheaka exploratory well (State well number 3-3204-01), Oahu, Hawaii. . . . . . . . . . . . 8

4. Construction data for wells drilled during the study, Oahu, Hawaii . . . . . . . . . . . . . . . . . 10

\section{Conversion Factors}

\begin{tabular}{rll}
\hline Multiply & By & To obtain \\
\hline foot (ft) & 0.3048 & meter \\
mile (mi) & 1.609 & kilometer \\
inch (in.) & 25.4 & millimeter \\
\hline
\end{tabular}

Elevations in this report are referenced relative to mean sea level. 


\title{
Drilling, Construction, and Caliper-Log Data for Well 3-3204-01, Kaheaka Exploratory Well, Oahu, Hawaii
}

\author{
By Todd K. Presley and Delwyn S. Oki
}

\begin{abstract}
The Kaheaka exploratory well (State well number 3-3204-01) was drilled about 3.3 miles southeast of the town of Haleiwa. The well is on agricultural land in the Waialua ground-water area. The well penetrates about 67 feet into a basalt aquifer. Well-construction data, logs of drilling notes, geologic descriptions for the samples, and caliper$\log$ data are presented for the well. The well is one of 12 exploratory wells drilled in the north-central Oahu area between July 1993 and May 1994 in cooperation with the Honolulu Board of Water Supply.
\end{abstract}

\section{INTRODUCTION}

Because of water-supply concerns associated with population increase on the island of Oahu, the Honolulu Board of Water Supply in cooperation with the U.S. Geological Survey (USGS) conducted a study to assess the availability of ground water in north-central Oahu. This study included drilling 12 exploratory and monitoring wells between July 1993 and May 1994.

This report presents drilling data for Kaheaka exploratory well (State well number 3-3204-01). The well is located about $3.3 \mathrm{mi}$ southeast of the town of Haleiwa (figs. 1 and 2). The purpose of the Kaheaka exploratory well is to increase spatial coverage of water-levels in the Waialua ground-water area (Rosenau and others, 1971; Dale, 1978; Hunt, in press) and to provide a water-level observation well for monitoring.

\section{Regional Setting}

The study area is located in north-central Oahu between the crests of the Koolau Range and the Waianae Range (fig. 1). The mountain ranges are the eroded remnants of two shield volcanoes. The mountain ranges are the eroded remnants of two shield volcanoes. The Mokuleia ground-water area lies within the basalt aquifer of the Koolau Volcano. Previous studies (Rosenau and others, 1971; Dale, 1978; Hunt, in press) that describe the physical and geological aspects of the ground-water area are summarized here. The Mokuleia and Waialua ground-water areas are separated by lowpermeability paleosols and saprolite of the Waianae Volcano that lie below the geologic contact between the Waianae and Koolau Volcanoes. The Waialua and Kawailoa ground-water areas are separated by alluvium and weathered basalt in and beneath Anahulu Gulch. Seaward flow of ground water in the Mokuleia and Waialua ground-water areas is impeded by a coastal confining unit that is composed of marine and terrestrial sediment known locally as "caprock." The caprock creates a confined artesian condition at low elevations near the shore. Further inland however, the aquifer is unconfined.

Water levels in the Waialua and Kawailoa groundwater areas are about $12 \mathrm{ft}$ and $4 \mathrm{ft}$ above mean sea level, respectively. Water levels in the Mokuleia groundwater area are about $20 \mathrm{ft}$. Withdrawal from the Waialua, Kawailoa and Mokuleia ground-water areas is primarily for sugarcane irrigation, although there are also several municipal wells and numerous small capacity private wells. Natural ground-water discharge occurs at springs and by subsurface flow through the caprock to the ocean (Rosenau and others, 1971). 


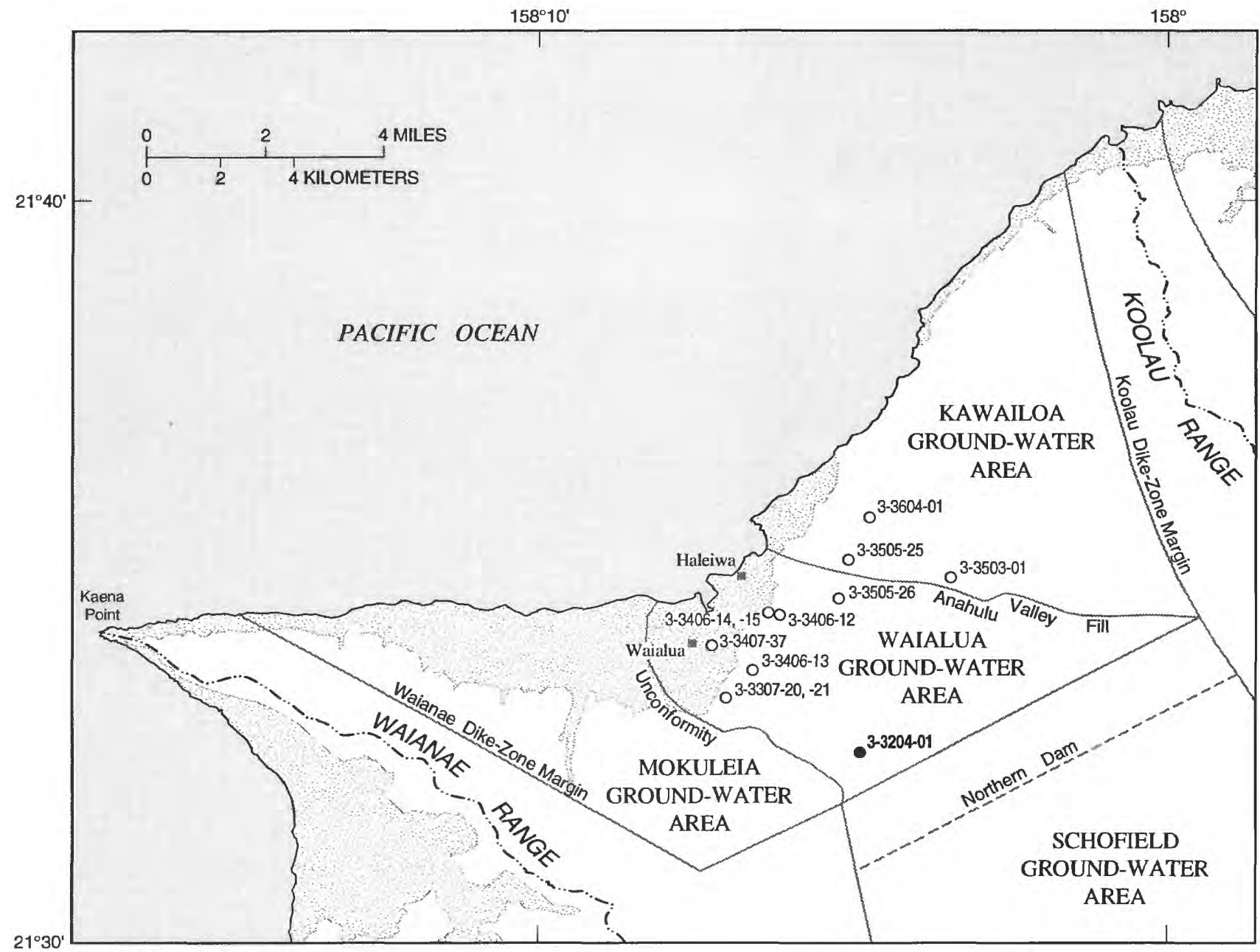

Base modified from U.S. Geological Survey

digital data, 1:24,000, 1983. Albers equal area

projection, standard paraliels $21^{\circ} 15^{\prime}$ and $21^{\circ} 45^{\prime}$

central meridian $157^{\circ} 59^{\prime}$

EXPLANATION

SEDIMENTARY DEPOSITS (CAPROCK)

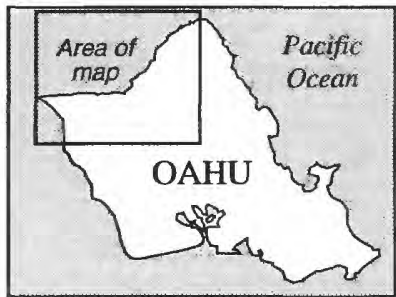

BOUNDARY OF GROUND-WATER AREA

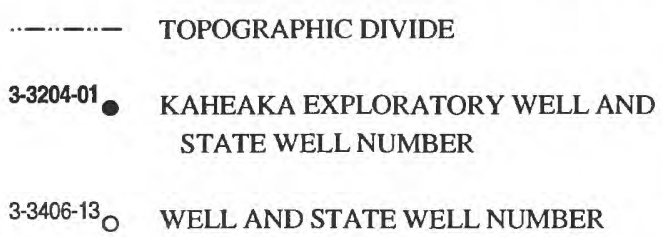

Figure 1. Ground-water areas of north-central Oahu (modified from Hunt, in press) and wells drilled during the study, Hawaii. 


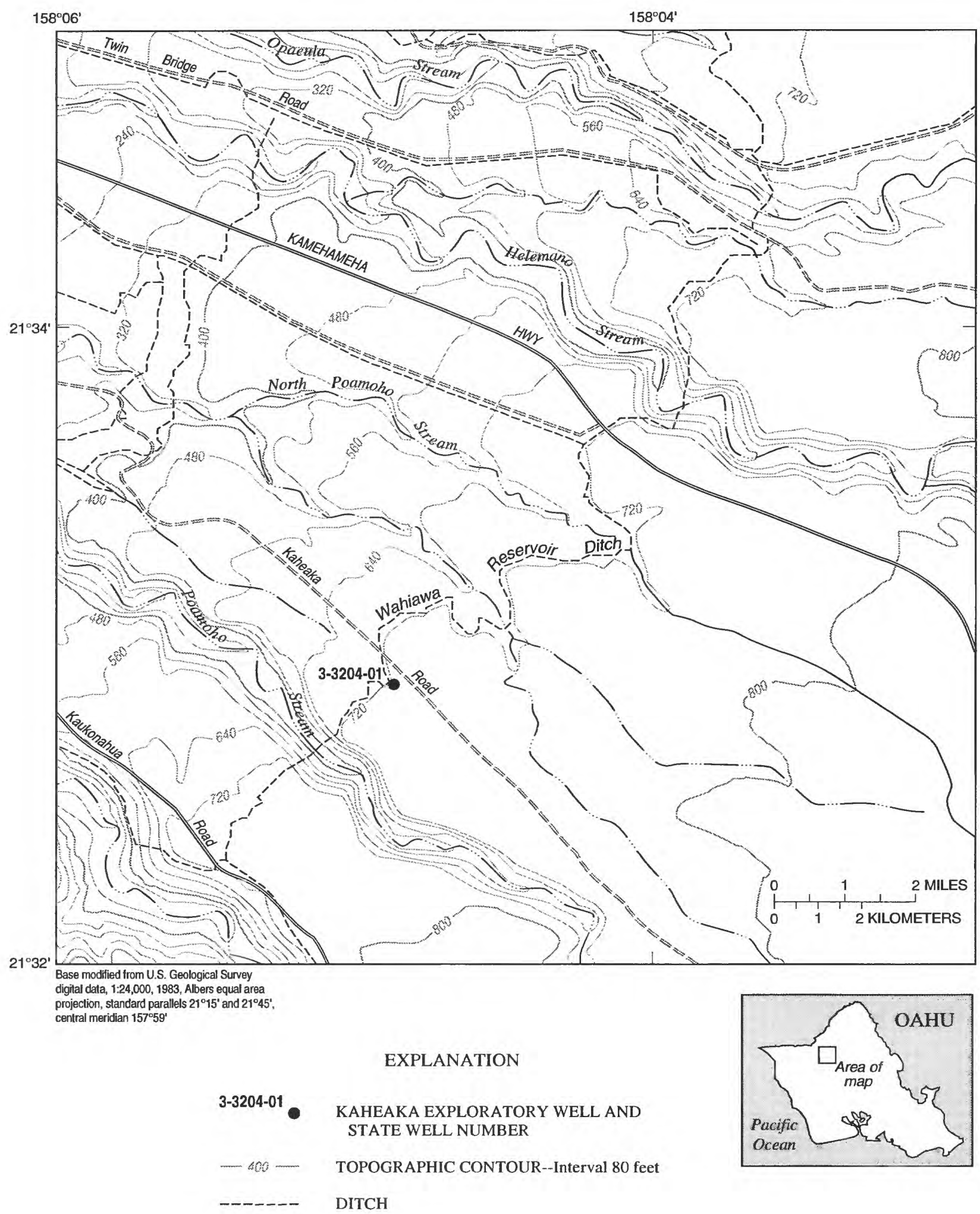

Figure 2. Location of Kaheaka exploratory well, Oahu, Hawaii. 


\section{Acknowledgments}

The USGS gratefully acknowledges the Waialua Sugar Company for their assistance in identifying and preparing the drill site. The USGS also thanks the Castle and Cooke Land Company for permission to drill on their land.

\section{DRILLING, CONSTRUCTION, AND CALIPER-LOG DATA}

The Kaheaka exploratory well (State well number 3-3204-01) is about $3.3 \mathrm{mi}$ southeast of the town of Haleiwa. The well is adjacent to a pineapple field, $30 \mathrm{ft}$ above the Wahiawa Reservoir Ditch between the southern tributary of North Poamoho Stream and Poamoho Stream, and about $500 \mathrm{ft}$ south of Kaheaka Road. Wellconstruction data is provided in table 1 and construction details are shown in figure 3.

The Kaheaka exploratory well was drilled using an air-rotary system with flush-jointed 4 1/2-in. diameter drill pipe. Drilling foam and polymer were injected into the air-circulation system to assist the removal of drill cuttings and to stabilize the hole. The elevation of the ground surface in the area of the drill site is about 740 $\mathrm{ft}$. A 12 1/2-in. diameter hole was drilled to an elevation of $643 \mathrm{ft}$ and cased with about $99 \mathrm{ft}$ of $85 / 8$-in. outside- diameter steel casing to provide a surface seal. The annular space was grouted with cement. A $63 / 4$-in. diameter tri-cone tungsten-carbide button bit was then used to drill to an elevation of $-55 \mathrm{ft}$. Before casing the well, a caliper log of the well was recorded using a Well Reconnaissance logging unit. The well was cased with 4 1/2-in. outside-diameter flush-jointed steel casing. Slotted, 4 1/2-in. outside-diameter steel casing was installed through the water column.

The caliper log (fig. 4) shows many hole enlargements where the caliper arms extend up to about 12 in. and three hole enlargements of at least $30 \mathrm{in}$. at elevations of about 487,130 , and $100 \mathrm{ft}$. The narrowing of the caliper log below the 100 -ft elevation is an artifact of the instrumentation. The caliper tool has three 16-in. spring-loaded arms that are extended when the tool is at the bottom of the hole. As the tool is raised, the logging unit records the extension of the arms as they drag against the walls of the bore. The caliper extension record is an indication of hole diameter and wall smoothness, but the instrument does not measure these attributes directly. The maximum extension for the caliper tool is 32 in.

Samples of the materials expelled by the circulation system while drilling were collected every 5 to 20 $\mathrm{ft}$. Circulation was intermittent between the 643- and 566-ft elevations and was completely absorbed with no

Table 1. Construction data for Kaheaka exploratory well, Oahu, Hawaii [Elevation datum is mean sea level; in., inch; ft, feet; od, outside diameter]

\begin{tabular}{|c|c|}
\hline Well name $\ldots \ldots \ldots \ldots \ldots \ldots \ldots \ldots \ldots \ldots \ldots \ldots \ldots$ & Kaheaka exploratory Well \\
\hline State well number $\ldots \ldots \ldots \ldots \ldots \ldots \ldots \ldots \ldots \ldots$ & 3-3204-01 \\
\hline Latitude and longitude.$\ldots \ldots \ldots \ldots \ldots \ldots \ldots \ldots \ldots$ & $21^{\circ} 32^{\prime} 52^{\prime \prime} \mathrm{N}, 158^{\circ} 04^{\prime} 52^{\prime \prime} \mathrm{W}$ \\
\hline Hawaii tax map key number $\ldots \ldots \ldots \ldots \ldots \ldots \ldots$ & $6-5-01-2$ \\
\hline Landowner. . . . . $\ldots \ldots \ldots \ldots \ldots \ldots \ldots \ldots \ldots \ldots$ & Castle and Cooke Land Company \\
\hline Leaseholder.$\ldots \ldots \ldots \ldots \ldots \ldots \ldots \ldots \ldots \ldots \ldots \ldots \ldots \ldots \ldots \ldots \ldots$ & Waialua Sugar Company \\
\hline Well completed $\ldots \ldots \ldots \ldots \ldots \ldots \ldots \ldots \ldots \ldots$ & March 2, 1994 \\
\hline Working days to complete.$\ldots \ldots \ldots \ldots \ldots \ldots \ldots$ & 16 days \\
\hline 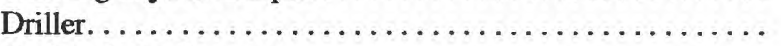 & Wayne Heick, USGS \\
\hline Surface hole diameter $\ldots \ldots \ldots \ldots \ldots \ldots \ldots \ldots \ldots \ldots$ & $121 / 2$ in. \\
\hline 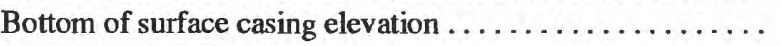 & $643 \mathrm{ft}$ \\
\hline Surface casing diameter and type $\ldots \ldots \ldots \ldots \ldots \ldots$ & $85 / 8$-in. od steel, 0.188 -in. thick wall \\
\hline Final hole diameter $\ldots \ldots \ldots \ldots \ldots \ldots \ldots \ldots \ldots \ldots \ldots \ldots \ldots \ldots$ & $63 / 4$ in. \\
\hline Bottom of well elevation $\ldots \ldots \ldots \ldots \ldots \ldots \ldots \ldots \ldots$ & $-55 \mathrm{ft}$ \\
\hline Open interval elevations $\ldots \ldots \ldots \ldots \ldots \ldots \ldots \ldots \ldots$ & $643 \mathrm{ft}$ to $-55 \mathrm{ft}$ \\
\hline Screened interval elevations $\ldots \ldots \ldots \ldots \ldots \ldots \ldots$ & $25 \mathrm{ft}$ to $-55 \mathrm{ft}$ \\
\hline Inner casing diameter and type $\ldots \ldots \ldots$ & $41 / 2$-in. od steel, flush-jointed \\
\hline 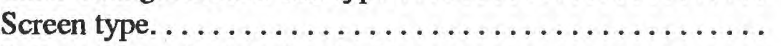 & $41 / 2$-in. od steel, slots cut longitudinally, $0.25 \times 3.0 \mathrm{in}$. \\
\hline Reference mark elevation (bolt) $\ldots \ldots \ldots \ldots \ldots \ldots \ldots$ & $740.60 \mathrm{ft}$ \\
\hline Top of casing measuring point elevation. . . . . . . . . & $741.59 \mathrm{ft}$ (top of $41 / 2$-in. inner casing) \\
\hline Water level and date of measurement $\ldots \ldots \ldots \ldots \ldots \ldots$ & $12.44 \mathrm{ft}$, January 27,1995 \\
\hline
\end{tabular}




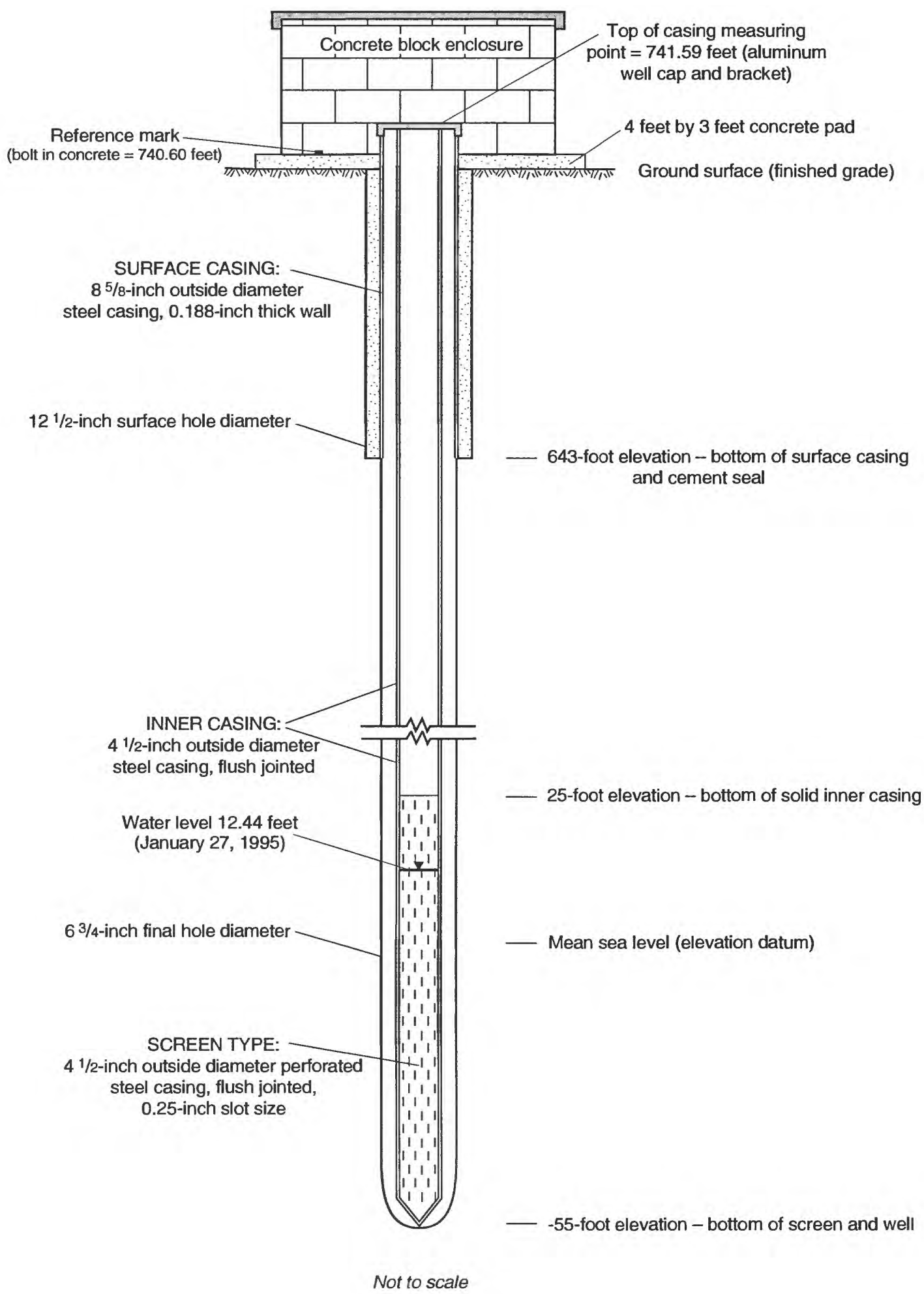

Figure 3. Construction details for Kaheaka exploratory well (State well number 3-3204-01), Oahu, Hawaii. 


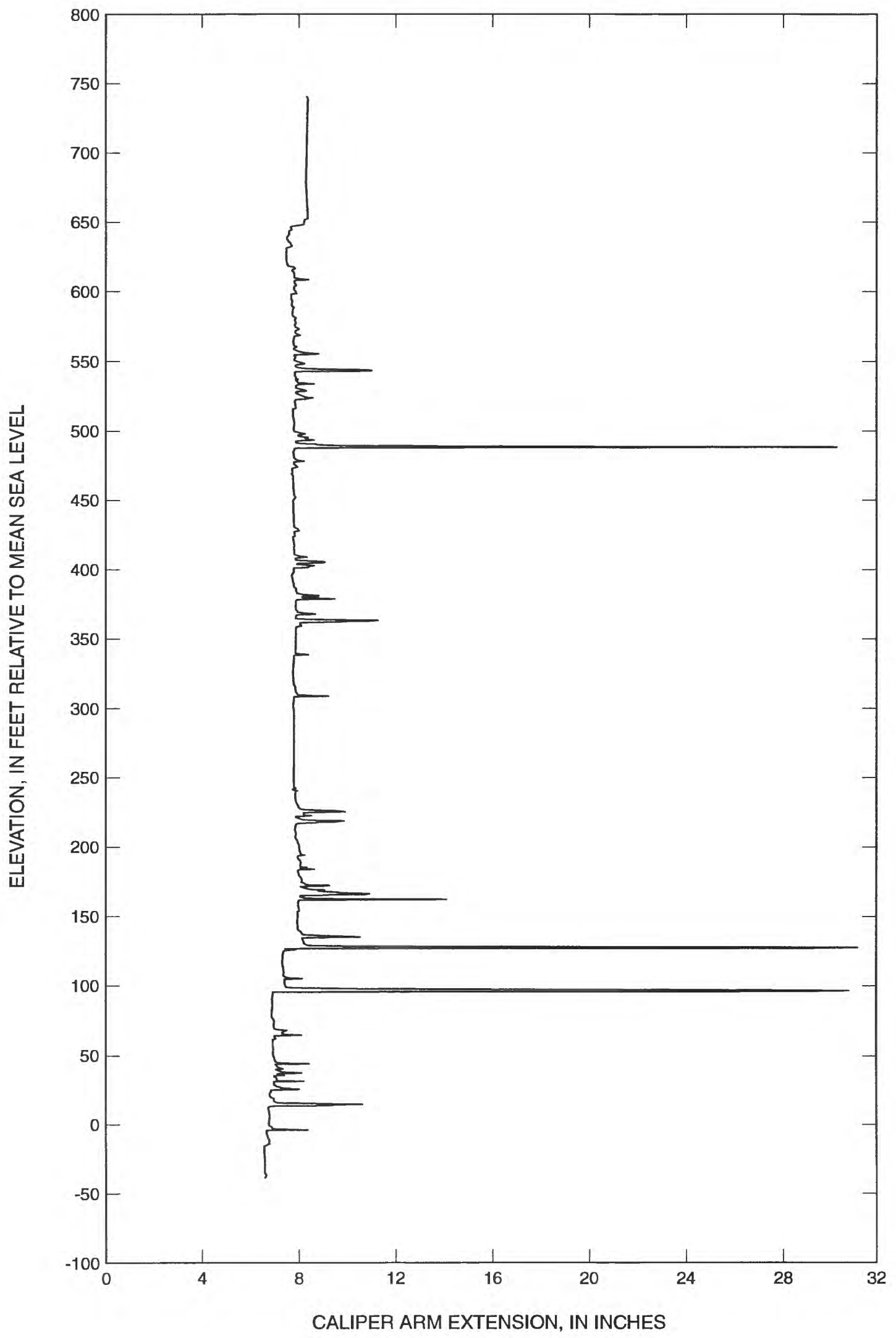

Figure 4. Caliper log for Kaheaka exploratory well (State well number 3-3204-01), Oahu, Hawaii. 
sample recovery after reaching the 566-ft elevation. The geologic log (geologic descriptions of the recovered samples from drilling) is presented in table 2 , and the driller's log (driller's observations while drilling) is presented in table 3. From the surface, the bore penetrated about $90 \mathrm{ft}$ of saprolite and $60 \mathrm{ft}$ of weathered basalt before losing circulation.

The measuring point (elevation $741.59 \mathrm{ft}$ ) for water-level determination by measuring tape is located on the top of the south side of the inner 4 1/2-in. outsidediameter steel casing. An additional reference mark (elevation $740.60 \mathrm{ft}$ ) for the well site is located on the top of a stainless steel bolt emplaced into a concrete pad surrounding the well.

The well was drilled close to the weathered contact that serves as the barrier between the Mokuleia and Waialua ground-water areas, however, water levels in this well are reflective of Waialua ground-water area water levels, which are about $12 \mathrm{ft}$.

\section{ADDITIONAL INFORMATION}

Information for the 12 wells drilled during the north-central Oahu study is listed in table 4 . Nine of the wells, including the Kaheaka exploratory well (State well number 3-3204-01), were drilled in the Waialua ground-water area, and three wells were drilled north of Anahulu Gulch in the Kawailoa ground-water area. Water-level time-series data were collected for all of the wells drilled and for numerous other existing wells as part of the overall monitoring effort for the project (unpublished data in files of the USGS, Honolulu). Data were collected using electronic data loggers coupled to shaft encoder-float systems or pressure transducers.

\section{REFERENCES CITED}

Dale, R.H., 1978, A ground-water inventory of the Waialua basal-water body, island of Oahu, Hawaii: U.S. Geological Survey Open-File Report 78-24, 71 p.

Hunt, C.D. Jr., in press, Geohydrology of the island of Oahu, Hawaii: U.S. Geological Survey Professional Paper 1412-B.

Rosenau, J.C., Lubke, E.R., and Nakahara, R.H., 1971, Water resources of north-central Oahu, Hawaii: U.S. Geological Survey Water-Supply Paper 1899-D, 40 p.

Table 2. Geologic log for Kaheaka exploratory well (State well number 3-3204-01), Oahu, Hawaii [Elevation datum is mean sea level]

\begin{tabular}{clll}
\hline $\begin{array}{c}\text { Depth below } \\
\text { grade (feet) }\end{array}$ & $\begin{array}{c}\text { Elevation } \\
\text { (feet) }\end{array}$ & Sample description & Comments \\
\hline 0 to 5 & 740 to 735 & Red soil & \\
5 to 10 & 735 to 730 & Red, hard soil & \\
10 to 15 & 730 to 725 & Red, hard soil & Saprolite \\
15 to 26 & 725 to 714 & No sample & Saprolite \\
26 to 43 & 714 to 697 & Orangish-brown, weathered material & Saprolite \\
43 to 63 & 697 to 677 & Dark, greyish-brown, weathered material & Saprolite \\
63 to 83 & 677 to 657 & Reddish-brown, weathered material & Light-weight chunk \\
83 to 90 & 657 to 650 & Brownish-grey, weathered material & Aa core \\
104 to 114 & 636 to 626 & Light brownish-grey, weathered basalt & \\
114 to 134 & 626 to 606 & Dark-grey, slightly vesicular basalt & Dark-grey, highly vesicular, slightly oxidized basalt \\
154 to 174 & 586 to 566 & &
\end{tabular}


Table 3. Driller's log for Kaheaka exploratory well (State well number 3-3204-01), Oahu, Hawaii [Elevation datum is mean sea level]

\begin{tabular}{|c|c|c|}
\hline $\begin{array}{l}\text { Depth below } \\
\text { grade (feet) }\end{array}$ & $\begin{array}{c}\text { Elevation } \\
\text { (feet) }\end{array}$ & Description \\
\hline 0 to 10 & 740 to 730 & Clay, red and moist \\
\hline 10 to 36 & 730 to 704 & Red clay, moist with some rock \\
\hline 36 to 64 & 704 to 676 & Red-brown-blue, medium-soft rock \\
\hline 64 to 85 & 676 to 655 & Brown-gray, soft rock \\
\hline 85 to 99 & 655 to 641 & Hard blue rock, dry, casing set to here \\
\hline 99 to 108 & 641 to 632 & Brown-blue, hard rock \\
\hline 108 to 110 & 632 to 630 & Brown-red, medium-hard rock \\
\hline 110 to 115 & 630 to 625 & Brown-red, oxidized, soft rock; fracture zone \\
\hline 115 to 128 & 625 to 612 & Blue, hard rock \\
\hline 128 to 140 & 612 to 600 & Red-brown, oxidized, medium-hard rock \\
\hline 140 to 147 & 600 to 593 & Red-brown, oxidized, soft rock; very broken, lost circulation \\
\hline 147 to 150 & 593 to 590 & Red-brown, oxidized medium-soft rock, no return \\
\hline 150 to 151 & 590 to 589 & Medium-soft, blue rock; circulation regained \\
\hline 151 to 167 & 589 to 573 & Gray-brown medium-soft rock; good return \\
\hline 167 to 175 & 573 to 565 & Red-brown oxidized rock; broken and soft \\
\hline 175 to 193 & 565 to 547 & Very soft, clinker-like; several voids; lost circulation. \\
\hline 193 to 194 & 547 to 546 & Medium-hard, competent rock; no circulation \\
\hline 194 to 197 & 546 to 543 & Clinker-like; no circulation \\
\hline 197 to 199 & 543 to 541 & Medium-hard, competent rock, and clinkers; no circulation \\
\hline 199 to 203 & 541 to 537 & Clinker-like, loose rocks, voids; no circulation \\
\hline 203 to 213 & 537 to 527 & Competent rock, oxidized, medium soft, no circulation \\
\hline 213 to 214 & 527 to 526 & Medium-hard, competent rock; no circulation \\
\hline 214 to 229 & 526 to 511 & Very fractured, very soft, clinker-like rock; no circulation \\
\hline 229 to 234 & 511 to 506 & Medium-hard, stiff, competent rock; no circulation \\
\hline 234 to 248 & 506 to 492 & Very hard, competent rock; no circulation \\
\hline 248 to 255 & 492 to 485 & Medium-hard, loose rock; no circulation \\
\hline 255 to 257 & 485 to 483 & Void, tools dropped; no circulation \\
\hline 257 to 266 & 483 to 474 & Medium-hard, competent rock; no circulation \\
\hline 266 to 282 & 474 to 458 & Soft rock; no circulation \\
\hline 282 to 300 & 458 to 440 & Medium-hard, competent rock; no circulation \\
\hline 300 to 307 & 440 to 433 & Soft, broken rock; no circulation \\
\hline 307 to 314 & 433 to 426 & Competent, hard rock; no circulation \\
\hline 314 to 329 & 426 to 411 & Loose, broken, soft rock; no circulation \\
\hline 329 to 332 & 411 to 408 & Hard, broken rock; no circulation \\
\hline 332 to 336 & 408 to 404 & Medium-soft, broken, rock; no circulation \\
\hline 336 to 353 & 404 to 387 & Very broken, very soft rock; no circulation \\
\hline 353 to 362 & 387 to 378 & Competent, hard rock; no circulation \\
\hline 362 to 433 & 378 to 307 & Medium-soft to soft rock; no circulation \\
\hline 433 to 440 & 307 to 300 & Medium-hard to hard, competent rock; no circulation \\
\hline 440 to 451 & 300 to 289 & Medium-soft to soft rock; no circulation \\
\hline 451 to 463 & 289 to 277 & Medium-hard, competent rock; no circulation \\
\hline 463 to 493 & 277 to 247 & Medium-soft rock; no circulation \\
\hline 493 to 498 & 247 to 242 & Medium-hard, competent rock; no circulation \\
\hline 498 to 505 & 242 to 235 & Loose, clinker-like, medium-soft rock; no circulation \\
\hline 505 to 509 & 235 to 231 & Medium-hard, competent rock; no circulation \\
\hline 509 to 550 & 231 to 190 & Clinker-like, rough going; no circulation \\
\hline 550 to 557 & 190 to 183 & Medium-hard, competent rock; no circulation \\
\hline 557 to 570 & 183 to 170 & Soft rock with gas-pocket like voids; no circulation \\
\hline 570 to 579 & 170 to 161 & Medium-hard, competent rock; no circulation \\
\hline 579 to 590 & 161 to 150 & Soft with many voids; no circulation \\
\hline 590 to 591 & 150 to 149 & Big void; no circulation \\
\hline 591 to 596 & 149 to 144 & Medium-hard, competent rock; no circulation \\
\hline 596 to 611 & 144 to 129 & Soft rock with voids; no circulation \\
\hline 611 to 624 & 129 to 116 & Medium-hard, competent rock; no circulation \\
\hline
\end{tabular}


Table 3. Driller's log for Kaheaka exploratory well (State well number 3-3204-01), Oahu, Hawaii --Continued [Elevation datum is mean sea level]

\begin{tabular}{lcl}
\hline $\begin{array}{c}\text { Depth below } \\
\text { grade (feet) }\end{array}$ & $\begin{array}{c}\text { Elevation } \\
\text { (feet) }\end{array}$ & \\
\hline 624 to 626 & 116 to 114 & Void; no circulation \\
626 to 654 & 114 to 86 & Medium-soft rock with many voids; no circulation \\
654 to 658 & 86 to 82 & Large void; no circulation \\
658 to 672 & 82 to 68 & Medium-soft to soft rock; no circulation \\
672 to 677 & 68 to 63 & Medium-hard, competent rock; no circulation \\
677 to 702 & 63 to 38 & Medium-soft rock, rough drilling, voids; no circulation \\
702 to 704 & 38 to 36 & Medium-hard, fractured rock; no circulation \\
704 to 711 & 36 to 29 & Medium-soft, clinker-like zone; no circulation \\
711 to 713 & 29 to 27 & Void, tools dropped; no circulation \\
713 to 715 & 27 to 25 & Medium-hard, competent rock; no circulation \\
715 to 727 & 25 to 13 & Broken, soft rock; no circulation, possibly reached water \\
727 to 738 & 13 to 2 & Medium-hard, competent rock; no circulation \\
738 to 746 & 2 to -6 & Soft, broken rock, many small voids; no circulation, water reached \\
746 to 770 & -6 to -30 & Medium-hard, competent rock, many voids; no circulation \\
770 to 774 & -30 to -34 & Fractured, broken, very soft rock; no circulation \\
774 to 784 & -34 to -44 & Competent rock; no circulation, definitely into water \\
784 to 790 & -44 to -50 & Broken, soft rock; no circulation, uneven drilling \\
790 to 794 & -50 to -54 & Medium-hard, competent rock; no circulation \\
794 to 797 & -54 to -57 & Soft rock; no circulation \\
\hline
\end{tabular}




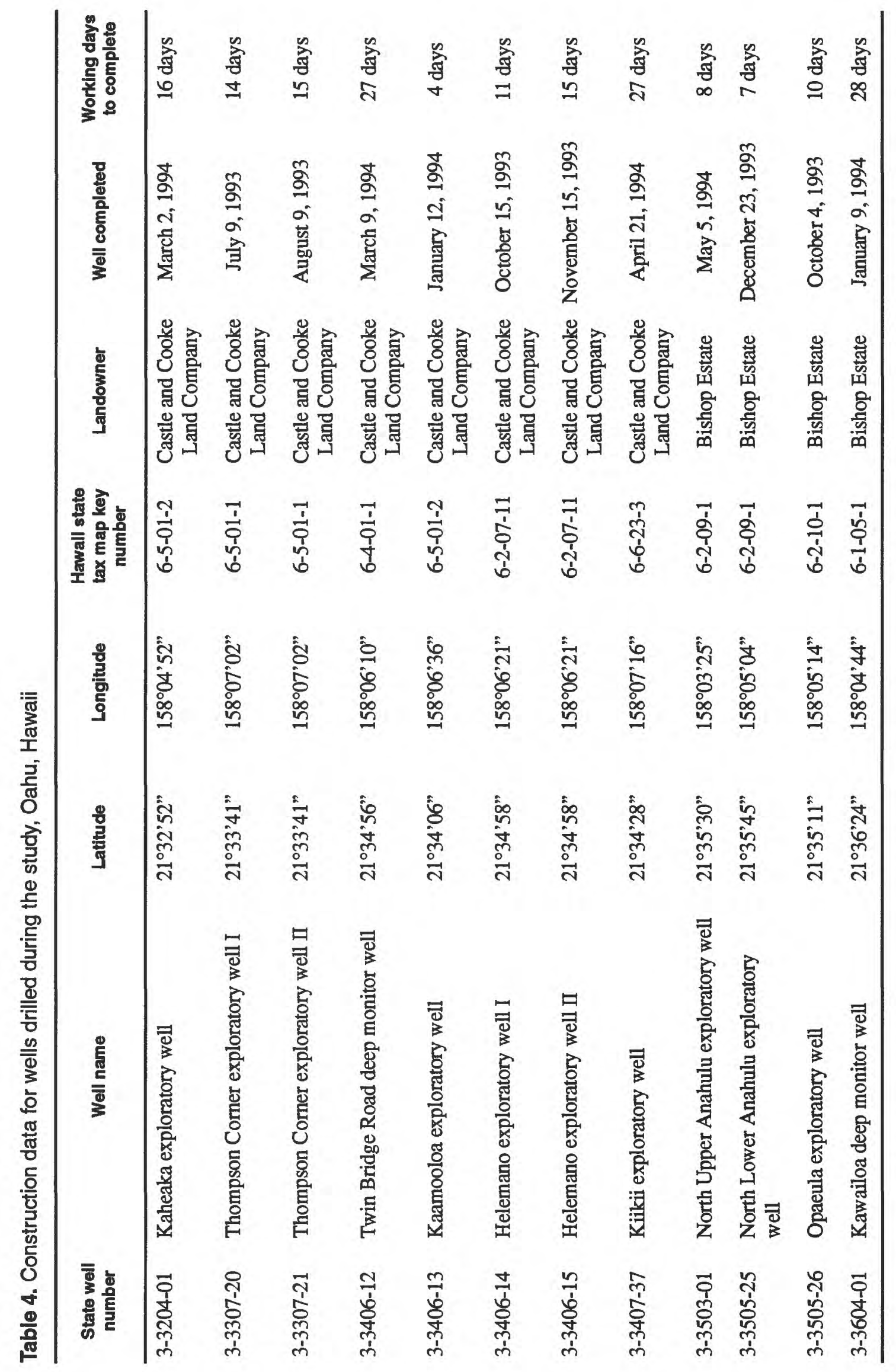




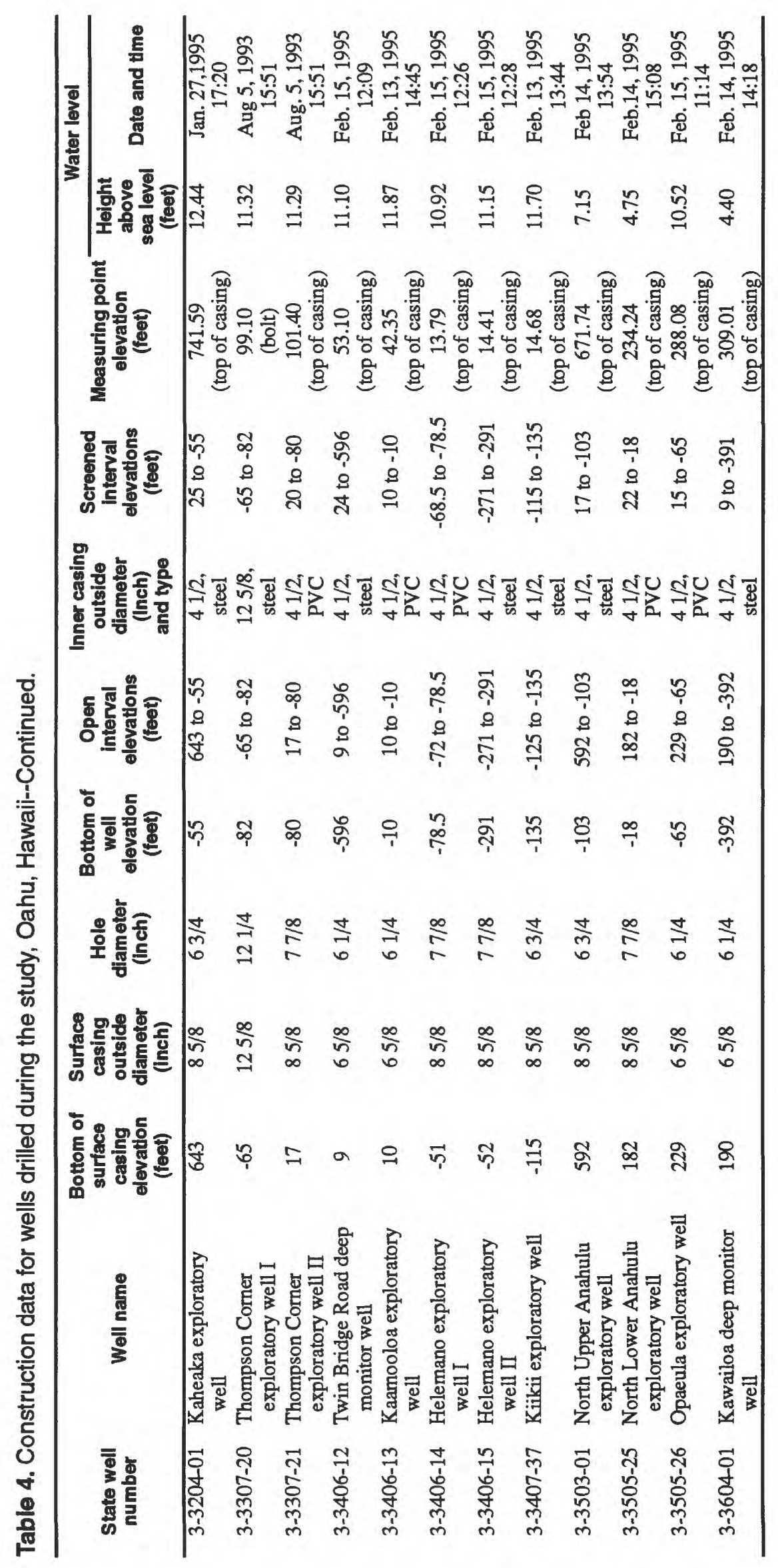

